Original Research Article

\title{
A study of effect of acute and chronic administration of aqueous extract of Calotropis procera leaves on maximal electroshock induced seizures in rats
}

\author{
Megha Madhyastha ${ }^{1}$, Smita Shenoy ${ }^{2}$, Vagdevi Hangarakatte Ramachandra ${ }^{3}$, \\ Rajappayya Desai $^{4}$, Amod Tilak ${ }^{2}$, Meena Kumari ${ }^{2}$, Manjunath Shetty ${ }^{5}$
}

\begin{abstract}
${ }^{1}$ Clinical Data Coordinator, Quintiles Research India Pvt Ltd., Bangalore, Karnataka 576104, India

${ }^{2}$ Department of Pharmacology, Kasturba Medical College, Manipal, Manipal University, Karnataka 576104, India ${ }^{3}$ Department of Pharmacology, Subbaiah Institute of Medical Sciences, Shimoga, Karnataka, India

${ }^{4}$ Department of Pharmacology, Gadag Institute of Medical Sciences, Gadag, Karnataka, India

${ }^{5}$ Department of Pharmacology, Melaka Manipal Medical College, Manipal, Karnataka 576104, India
\end{abstract}

Received: 16 November 2016 Accepted: 25 November 2016

*Correspondence to:

Dr. Rajappayya Desai, Email:

rajappayyadesai@gmail.com

Copyright: (C) the author(s), publisher and licensee Medip Academy. This is an openaccess article distributed under the terms of the Creative Commons Attribution NonCommercial License, which permits unrestricted noncommercial use, distribution, and reproduction in any medium, provided the original work is properly cited.

\section{ABSTRACT}

Background: The effect of acute and chronic administration of aqueous extract of leaves of Calotropis procera on maximal electroshock (MES) induced seizures in rats was evaluated.

Methods: Four groups of wistar rats were treated with distilled water $10 \mathrm{~mL} / \mathrm{kg}$ (oral), phenytoin $25 \mathrm{mg} / \mathrm{kg}$ (intraperitoneal), $250 \mathrm{mg} / \mathrm{kg}$ (oral) and $500 \mathrm{mg} / \mathrm{kg}$ (oral) of aqueous extract of leaves of $C$ procera, respectively in both acute and chronic studies. For producing maximal electroshock seizures, an electroconvulsiometer was used to deliver an electric stimulus of $150 \mathrm{~mA}$ for 0.2 sec. The duration of hind limb extension (HLE) and seizures were noted in seconds (sec). In the acute study, the shock was given $1 \mathrm{~h}$ after administration of drugs. For the chronic study, all drugs were administered for 6 weeks. One hour after the last dose of drugs, the shock was administered. Data was analyzed by one way ANOVA followed by Tukey's post hoc test.

Results: There was a significant decrease in the duration of hind limb extension, and convulsions as compared to control following acute ( $p<0.01$ vs control) and chronic ( $\mathrm{p}<0.05$ vs control) administration of aqueous extract of leaves of Calotropis procera in rats.

Conclusions: The study demonstrated that aqueous extract of $C$ procera leaves resulted in significant protection against maximal electroshock induced seizures in rats.

Keywords: Tonic hind limb extension, Phenytoin

\section{INTRODUCTION}

Epilepsy is characterized by seizures which is due to excessive, abnormal and asynchronous neuronal activity in the brain. ${ }^{1}$ Though many antiepileptic drugs are 
available, yet about $20-30 \%$ of patients are refractory to treatment. ${ }^{2}$ Hence, it is important to evaluate newer agents for treatment of epilepsy. Herbal remedies have been used for treatment of various diseases including epilepsy. Calotropis procera is known for its use in folklore medicine for the treatment of fever, jaundice, asthma, leprosy, diarrhea and painful joints. ${ }^{3,4}$

Calotropis procera has been used traditionally for treatment of epilepsy. The root and bark have been used for this purpose. ${ }^{5,6}$ Studies have demonstrated the anticonvulsant effect of roots of Calotropis procera in pentylenetetrazole and maximal electroshock induced seizures in rats. ${ }^{2}$ The leaves have shown to produce beneficial effect in pentylenetetrazole induced seizures in rats. ${ }^{7}$ This study was undertaken to study the acute and chronic effect of aqueous extract of leaves of Calotropis procera on maximal electroshock (MES) induced seizures in rats. Maximal electroshock (MES) induced seizures model is used for screening of drugs for anticonvulsant activity in generalised tonic clonic seizures. ${ }^{8,9}$

\section{METHODS}

\section{Preparation of extract}

The leaves of Calotropis procera were authenticated by a botanist following whom they were shade dried and coarsely ground. The powder was soaked in distilled water for seven days. The liquid was filtered and the filtrate was concentrated on water bath. The paste obtained was dried in a desiccator.

\section{Animals}

Adult Sprague dawley male rats weighing 150-200g were used. They were housed individually in polypropylene cages and maintained at a temperature of $27 \pm 3^{\circ} \mathrm{C}$, relative humidity of $60 \pm 10 \%$ and $12 \mathrm{~h}$ light/ dark cycle, standard diet and water ad libitum.

The maximal electroshock induced seizure model was used to study anticonvulsant activity of leaves (aqueous extract) of Calotropis procera following its acute and chronic administration in rats. Four groups of rats, with six rats in each group, were used for each acute and chronic study (total $=48$ rats). The doses of test and standard drugs were selected based on previous studies. ${ }^{1,7}$ The groups were as follows:

a) Group I (Control): Distilled water, $10 \mathrm{~mL} / \mathrm{kg}$ oral

b) Group II (Standard): Phenytoin, $25 \mathrm{mg} / \mathrm{kg}$, intraperitoneal (i.p).

c) Group III (Test): Aqueous extract of $C$ procera leaves, $250 \mathrm{mg} / \mathrm{kg}$ oral

d) Group IV (Test): Aqueous extract of $C$ procera leaves, $500 \mathrm{mg} / \mathrm{kg}$ oral

\section{Maximal electroshock (MES) induced seizure model}

Twenty four hours before the study, rats were screened to check whether they could develop full tonic extension when shock was administered. Those rats which developed full tonic extension were selected for the study. On the day of experiment, seizures were induced by an electro-convulsiometer (Technoelectronics Ltd., Lucknow, India) using a current of $150 \mathrm{~mA}, 50 \mathrm{~Hz}$ delivered through the ear clip electrodes for $0.2 \mathrm{sec}^{8}$ Duration of hind limb tonic extension (HLTE) and seizures was recorded. Abolition or decrease in the duration of tonic extension was considered to be indicative for antiepileptic activity. ${ }^{8}$ If extension of the hind limb was not more than 90 degree angle with the plane of the body, then the tonic component was considered to be abolished. ${ }^{10-12}$

\section{Acute study}

Four groups of rats were treated with drugs (as described above) followed by administration of electric stimulus $1 \mathrm{~h}$ later. $^{13}$

\section{Chronic study}

All drugs were administered to four groups of rats for 6 weeks. One hour after the last dose of drug, an electrical stimulus was administered. ${ }^{13}$ After observing the parameters, rats were sacrificed, brain was dissected, homogenized and GABA was estimated. ${ }^{14}$

\section{Statistical analysis}

Data was expressed as mean \pm SEM and analyzed using one way ANOVA followed by post hoc Tukey test. The level of significance was set at $\mathrm{P}<0.05$.

\section{RESULTS}

\section{Acute study}

Following acute administration of aqueous extract of leaves of Calotropis procera, there was a significant decrease $(\mathrm{p}<0.01$ vs control) in duration of hind limb extension and seizures as compared to control group (Table 1). There was no significant difference in effect between phenytoin and plant extract treated groups on duration of HLE and seizures.

\section{Chronic study}

Chronic administration of high dose $(500 \mathrm{mg} / \mathrm{kg})$ of aqueous extract of leaves of Calotropis procera, resulted in a significant decrease ( $\mathrm{p}<0.05$ vs control) in duration of hind limb extension and seizures as compared to control group (Table 2). There was no significant difference between effect of phenytoin and plant extract $(500 \mathrm{mg} / \mathrm{kg})$ on duration of HLE and seizures. There was 
no significant change in GABA levels in brain homogenate (Table 2).

Table 1: Effect of acute administration of aqueous extract of leaves of Calotropis procera on maximal electroshock induced seizures.

\begin{tabular}{|llll|}
\hline Group & Drug, dose & $\begin{array}{l}\text { HLE in seconds } \\
(\text { Mean } \pm \text { SEM) }\end{array}$ & $\begin{array}{l}\text { Total duration of convulsions } \\
\text { in seconds (Mean } \pm \text { SEM) }\end{array}$ \\
\hline 1 (control) & Distilled water, $10 \mathrm{~mL} / \mathrm{kg}$ & $12.33 \pm 1.86$ & $39.66 \pm 9.85$ \\
\hline 2 (standard) & Phenytoin, $25 \mathrm{mg} / \mathrm{kg}$ & $3.66 \pm 1.0^{*}$ & $9.33 \pm 1.86^{*}$ \\
\hline 3 (test) & $\begin{array}{l}\text { Aqueous extract of leaves of Calotropis } \\
\text { procera, } 250 \mathrm{mg} / \mathrm{kg}\end{array}$ & $7.5 \pm 1.5^{*}$ & $17.16 \pm 4.66^{*}$ \\
\hline 4 (test) & $\begin{array}{l}\text { Aqueous extract of leaves of Calotropis } \\
\text { procera, } 500 \mathrm{mg} / \mathrm{kg}\end{array}$ & $4.5 \pm 1.0^{*}$ & $12.33 \pm 4.13^{*}$ \\
\hline
\end{tabular}

${ }^{*} \mathrm{p} \leq 0.01$ versus control

Table 2: Effect of chronic administration of aqueous extract of leaves of Calotropis procera on maximal electroshock induced seizures.

\begin{tabular}{|lllll|}
\hline Group & Drug, dose & $\begin{array}{l}\text { HLE in seconds } \\
(\text { Mean }+ \text { SEM) }\end{array}$ & $\begin{array}{l}\text { Total duration of } \\
\text { convulsions in seconds } \\
\text { (Mean } \pm \text { SEM) }\end{array}$ & $\begin{array}{l}\text { GABA in } \\
\mu \text { mol/g } \\
\text { (Mean } \pm \text { SEM) }\end{array}$ \\
\hline 1 (control) & Distilled water, $10 \mathrm{~mL} / \mathrm{kg}$ & $10 \pm 0.34$ & $26.33 \pm 1.17$ & $85.94 \pm 13.4$ \\
\hline 2 (standard) & Phenytoin, $25 \mathrm{mg} / \mathrm{kg}$ & $5.3 \pm 0.48^{*}$ & $18.1 \pm 1.04^{*}$ & $100.8 \pm 18.5$ \\
\hline 3 (test) & $\begin{array}{l}\text { Aqueous extract of leaves of } \\
\text { Calotropis procera, } 250 \mathrm{mg} / \mathrm{kg}\end{array}$ & $7.1 \pm 0.31^{*}$ & $21.50 \pm 1.25$ & $89.6 \pm 11.6$ \\
\hline 4 (test) & $\begin{array}{l}\text { Aqueous extract of leaves of } \\
\text { Calotropis procera, } 500 \mathrm{mg} / \mathrm{kg}\end{array}$ & $6.6 \pm 0.26^{*}$ & $17.33 \pm 2.31^{*}$ & $92.8 \pm 30.09$ \\
\hline
\end{tabular}

$* p \leq 0.05$ versus control

\section{DISCUSSION}

The maximal electroshock induced seizure model helps to identify drugs which are effective against generalised tonic clonic seizures. Seizures induced in this model are indicative of grand mal epilepsy. If a drug abolishes or reduces the duration of the tonic hind-limb extensor phase or seizures in the MES model, then it has potential to be effective in grand mal epilepsy. ${ }^{15-18}$ In this study, the effect of Calotropis procera on duration of hind limb extension and convulsions was assessed and compared with phenytoin. The standard antiepileptic drug phenytoin significantly reduced the duration of tonic hind-limb extensor phase and seizures. The high dose of plant extract in our study produced a significant decrease in both parameters both on acute and chronic administration which indicates its anticonvulsant activity. There are various mechanisms by which drugs produce their action in GTCS. Drugs like phenytoin, carbamazepine, valproate, lamotrigine etc. act by prolonging the inactivated state of sodium channels. Drugs that increase gamma amino butyric acid (GABA) have exhibited anticonvulsant activity against seizures induced by MES. ${ }^{17,18}$ Brain homogenate levels of GABA was not significantly altered in rats treated with plant extract as compared to control. Free radicals have also been suggested to have a role in neuronal changes during MES. ${ }^{19}$ They enhance neuronal excitability thereby promoting abnormal discharge. The leaf of $C$ procera has been found to have antioxidant activities. This could have contributed to its beneficial effect in MES. ${ }^{20}$ Saponins, tannins and glycosides are important constituents of aqueous leaf extract of $C$ procera. ${ }^{21}$ Whether these were responsible for the beneficial effect in MES needs to be investigated. Further investigation is required to understand the mechanism of action of aqueous extract of Calotropis procera leaves by testing in other models of seizures.

\section{ACKNOWLEDGEMENT}

We acknowledge the support provided by Manipal University, Manipal.

Funding: No funding sources

Conflict of interest: None declared

Ethical approval: The study was approved by the Institutional Animal Ethics Committee, Manipal

\section{REFERENCES}

1. Gopi G, Jayasri P, Elumalai A. Anti-epileptic activity of Malachra capitata L. on maximal electroshock (MES) and pentylenetetrazole (PTZ) induced seizures models Int J Pharm Toxicol. 2012;2(2):104-8.

2. Jalalpure SS. Anticonvulsant effects of Calotropis procera root in rats. Pharm Biol. 2009;47(2):162-7. 
3. Abhishek D, Mohit C, Ashish G, Ameeta A. Medicinal utility of Calotropis procera (Ait.) R. Br. as used by natives of village Sanwer of Indore District, Madhya Pradesh. IJPLS. 2010;1(3):188-90.

4. Al-Snafi AE. The constituents and pharmacological properties of Calotropis procera - an overview. Int $\mathbf{J}$ Pharm Rev Res. 2015;5(3):259-75.

5. Chatterjee A, Prakash SC. In The Treatise of Indian Medicinal Plants. New Delhi, Publications and Information Directorate; 1994:130-1.

6. Nadakarni KM. In Indian Materia Medica. Popular Prakashan, Mumbai; 2002:242-7.

7. Vagdevi HR, Shenoy S, Madhyastha M, Desai R, Ghosh S. Evaluation of effect of aqueous extract of leaves of Calotropis procera in pentylenetetrazole induced seizures in rats. IJBCP. 2016;5(3):643-6.

8. Toman JEP, Swinyard EA, Goodman LS. Properties of maximal seizures, and their alteration by anticonvulsant drugs and other agents. J Neurophysiol. 1946;9(3):231-9.

9. Mareš P, Kubová H. Electrical stimulation-induced models of seizures. In models of seizures and epilepsy. Pitkänen A, Schwartzkroin PA, Moshé, SL (Eds.). Elsevier Academic Press: USA, 2006:153-9.

10. Snehunsu A, Mukunda N, Satish MC, Sadhana N, Sareesh NN, Kapgal VK, et al. Evaluation of antiepileptic property of Marsilea quadrifolia Linn. in maximal electroshock and pentylenetetrazole-induced rat models of epilepsy. Brain Inj. 2013;27(1314):1707-14.

11. Piredda SG, Woodhead JH, Swinyard EA. Effect of stimulus intensity on the profile of anticonvulsant activity of phenytoin, ethosuximide and valproate. J Pharmacol Exp Ther. 1985;232(3):741-5.

12. Dalby NO, Nielsen EB. Comparison of the preclinical anticonvulsant profiles of tiagabine, lamotrigine, gabapentin and vigabatrin. Epilepsy Res. 1997;28(1):63-72.

13. Kumar S, Megha M, Chogtu B, Bairy KL. Effect of acute and chronic administration of losartan, atorvastatin and their combination on animal models of epilepsy. RJPBCS. 2015;6(4):1795-801.

14. Habibur R, Eswaraiah MC. Simple spectroscopic methods for estimating brain neurotransmitters, antioxidants enzymes of laboratory animals like mice: a review. Pharmatutor Art 2008;1244.

15. White HS. Preclinical development of antiepileptic drugs: Past, present, and future directions. Epilepsia. 2003;44(7):2-8.

16. Löscher W, Schmidt D. Which animal models should be used in the search for new antiepileptic drugs? A proposal based on experimental and clinical considerations. Epilepsy Res 1988;2(3):145-81.

17. Meldrum B. Action of established and novel anticonvulsant drugs on the basic mechanisms of epilepsy. Epilepsy Res. 1996;11:67-77.

18. White HS. Clinical significance of animal seizure models and mechanism of action studies of potential antiepileptic drugs. Epilepsia. 1997;38(1):S9-17.

19. Bhosle V. Anticonvulsant and antioxidant activity of aqueous leaves extract of Desmodium triflorum in mice against pentylenetetrazole and maximal electroshock induced convulsion. Rev Bras Farmacogn Braz J Pharmacogn 2013;23(4):692-8

20. Murti Y, Yogi B, Pathak D. Pharmacognostic standardization of leaves of Calotropis procera (Ait.) R. Br. (Asclepiadaceae). Int J Ayurveda Res. 2010;1(1):14-7.

21. Yesmin MN, Uddin SN, Mubassara S, Akond MA. Antioxidant and antibacterial activities of Calotropis procera Linn. American-Eurasian J Agric Environ Sci. 2008;4(5):550-3.

Cite this article as: Madhyastha $\mathrm{M}$, Shenoy $\mathrm{S}$, Vagdevi HR, Desai R, Tilak A, Kumari M, et al. A study of effect of acute and chronic administration of aqueous extract of Calotropis procera leaves on maximal electroshock induced seizures in rats. Int $\mathbf{J}$ Basic Clin Pharmacol 2017;6:1-4. 